\title{
The Quality of Service Standards and Related Factors in Tourist Hotels in Arusha, Tanzania*
}

\author{
Naiman N. Mbise \\ National College of Tourism, Dar-es-Salaam, Tanzania \\ Dorcus Mbithe D-Kigaru, Moses Miricho \\ Kenyatta University, Nairobi, Kenya
}

\begin{abstract}
The gap in knowledge that existed between the level of service quality standard and the potential of the tourism industry in Tanzania justified the need for the researchers to conduct this study. In this study, a descriptive cross-sectional survey was adopted as the study design. The sample size included 180 guests residing in tourist hotels in Arusha at the time of data collection, 240 service employees, and 28 managers. Purposive, convenient, and simple random sampling methods were used in sampling. A structured questionnaire was used as an instrument of data collection. Data were analyzed by means of Statistical Package for Social Sciences (SPSS) computer package (Version 16) and expressed in descriptive and inferential statistics. The analysis of variance (ANOVA) was used to measure the gap between the managers' and guests' perceptions, while independent $t$-test analyzed the role played by managers' practices in delivery of quality service. The findings show that in general hotel product, two attributes were found to be significant at the level of $p \leq 0.05$. In the front office, restaurant and bar, and guestroom, the results showed that three, six, and nine attributes were respectively found to be significant at the level of $p \leq 0.05$. The analysis of management practices provided the evidence that eight practices were significant at the level of $p \leq 0.05$. From the findings, two conclusions were made. First, managers' and guests' perceptions on service quality standards differ significantly; second, it was found that management practices influence significantly the service quality standards in tourist hotels in Arusha.
\end{abstract}

Keywords: customer/guest requirement, service quality, guest/manager perceptions, quality attributes, management practices, service gap

\section{Introduction}

Hospitality and tourism industry in Tanzania contributes over 17\% to the national Gross Domestic Product (GDP) and is ranked the second in foreign exchange earnings after gold. It is estimated that, for every tourist arrival in Tanzania, 12 Tanzanians benefit directly and indirectly (Tanzania Tourist Board [TTB], 2008). In Tanzania, the development of hospitality industry started in the early 1970s and was wholly owned by state

\footnotetext{
${ }^{*}$ Acknowledgement: My sincere appreciation should go to my family for their immense support in preparation of this research paper.

Naiman N. Mbise, senior tutor, Department of Hospitality Management, National College of Tourism. Email: naiman22@yahoo.co.uk.

Dorcus Mbithe D-Kigaru, lecturer, Ph.D., Department of Food, Nutrition, and Dietetics, Kenyatta University.

Moses Miricho, lecturer, Department of Hospitality and Tourism, Kenyatta University.
} 
(United Republic of Tanzania [URT], 1999). This was different from the usual perspective of managing the hospitality and tourism industries, as it is widely known that the industry is a private sector motivated. Despite the fact that Tanzania had a lot to offer foreign tourists, the tourism industry found itself struggling for existence.

In the early 1990s, Tanzania liberated trade and adopted a free market economy which made state-owned businesses including hospitality business to be privatized. In that era, Tanzania witnessed a boom of investments in tourism enterprises, especially chain lodges and international hotels (URT, 1999). These changes were important for the hospitality and tourism industry to revitalize; however, the changes did not take into account the business environment factors. The industry struggled with staffs that were poor in language proficiency and communication skills, ending up with unqualified employees who could not provide services that met international standards (URT, 2002). Secondary school leavers were not interested in tourism careers, for example, they were not ready to take hotel, travel, and tourism operations courses and those took such courses did so because that was the only option available (URT, 2002). Parents had a negative perception that hospitality and tourism careers were for primary education or secondary education failures (URT, 1999). This led to the industry inheriting a labor force with poor performance at all levels. Thus, the main objective of this study was to establish the quality of service standards and related factors in tourist hotels in Arusha, Tanzania. This study set to achieve two specific objectives. The first objective was to determine the gap in perceptions between hotel managers and guests on quality of service standards. The second objective was to establish the role of management practices in delivery of service quality in tourist hotels in Arusha.

Designing the service quality package poses a big challenge to the hotel managers, as locking-in guest requirements is the most important aspect in meeting service quality, hence guest satisfaction. Hotel guests are always dynamic. This is because that changes which occur due to economic growth or decline, technology, and globalization affect the lifestyle, fashion, as well as customers' preferences and tastes (Kandampully, 2006). These changes impact on the service design and delivery. Therefore, understanding guests' requirements and having a correct service delivery plan and evaluation of the market will enable the hospitality firms to design a service quality package that fulfills guests' expectations (Sigala, 2008).

It is important to understand the way guests assess the service quality, parameters used in their assessment, and the way quality can be conceptualized. Literature has shown how guests evaluate the service quality offered by an organization. For the service organization to get feedback from the guests on the extent of service excellence, it is vital to understand how service quality is measured by the guests. The service quality refers to the perception of a guest against his/her expectation (Nadiri \& Hussein, 2005). The use of expectation as the means of benchmarking service quality in the hospitality industry has been debated by several researchers (O'Neill, 2001). This arises from the suggestions that expectations may not exist or be clear enough in the respondent's mind to act as a benchmarking against the perceptions assessed (O'Neill, 2001). Therefore, this study has defined the service quality as a level at which service performance from the hotel meets the customers' perceptions. In measuring the perceived service quality, researchers have used SERVQUAL model (Tsang \& Qui, 2000; Gržinic, 2007; Bagherian, 2007; Wadawi, 2008). SERVQUAL defines service quality using five parameters which include the following: tangibles (physical facilities, equipment, and personal appearance); reliability (dependability, accuracy, and consistence); responsiveness (willingness to provide prompt service and help customers); assurance (knowledge, competence, trust, confidence, and credibility); and empathy (caring service and individualized attention). 
The researchers assessed the perception to measure the service quality performance of the surveyed hotels. This direct approach of measuring the service quality has been advocated by many researchers (O'Neill, 2001). The approach utilized attributes of four areas of the hotel operations to evaluate the service quality of hotels as perceived by guests and managers.

The influences of management practices on ensuring that organizations deliver quality service expected by guests cannot be ignored. These managerial practices include employee selection, training, evaluation, rewarding, leading, and motivation. Several researchers have indicated the relationship between management practices and organization performance of a service firm (Pfeffer, 1998). Other researches include: the employee selection (Anderson, Provis, \& Chappel, 2003); training (Slåtten, 2009; Babakus, Yavas, Karatepe, \& Avci, 2003); the evaluation (Hartog \& Verburg, 2002); rewarding (Bowen \& Johnston, 1999; Bowen, Gilliland, \& Folger, 1999); and leadership styles (Clark, Hartline, \& Jones, 2009; Hickman \& Mayer, 2003). The literature review indicated the gap between the level of service quality standard and the potential of the tourism industry in Tanzania, hence the justification for the need and viability of this study.

\section{Methodology}

This study was conducted in Arusha city, which is the hub of tourism in Tanzania in particular and East Africa in general. This study adopted the cross-sectional descriptive survey. Tourists' and management's perceptions, skills possessed by service employees, and management practices were the independent variables and service quality delivered by tourists' hotel was the dependent variable. This study included foreign tourists residing in hotels in Arusha and service providers as its survey population. This study focused on foreign tourists, because most of the complaints on the level of service standards came from them. The sample size included 180 guests and was calculated by employing the formula of Cochran (1963).

The managers' sample size was determined by the census methods and a total of 28 managers were included in the sample. Published table (Israel, 2009) was used in estimating the sample size for service employees, where 240 service employees were included in the sample. Sampling procedures involved were convenient sampling for guests, purposive sampling for managers, and simple random sampling for service employees. A structured questionnaire was used in collection of information where the respondents were required to indicate their opinions on each statement on a 5-point Likert scale (from $1=$ strongly agree to $5=$ strongly disagree). Self-administration and personal interview were methods used in data collection. The research ethics were observed by ensuring that respondents and authorities were informed and their consent was sought before the research began. The students' research supervisors validated the questionnaire before it could be used for data collection. A fair response from the surveyed population was obtained. The responses of $56 \%, 53 \%$, and $70 \%$ were given by guests, employees, and managers respectively. Data were analyzed by Statistical Package for Social Sciences (SPSS) computer package (Version 16) and expressed in descriptive and inferential statistics. The one-way analysis of variance (ANOVA) was used to determine the significance of the gap observed between the managers' and guests' perceptions. The independent $t$-test was used to analyze the role played by management practices in delivery of quality service. 


\section{Results}

\section{Managers' Perceptions and Design of Quality Service}

As already pointed out, this study assessed managers' and guests' perceptions on service quality which aimed at finding out the gap between them. The findings showed that in general hotel product, out of seven attributes assessed, two were found to be significant at the level of $p \leq 0.05$. While in the front office, restaurant and bar, and guestroom, 14 attributes in each area were assessed; the results showed that three, six, and nine attributes were respectively found to be significant at the level of $p \leq 0.05$, as it is showed in Table 1.

Table 1

Significant Attributes to Service Quality Standards

\begin{tabular}{ll}
\hline Attribute of the areas & Level of significance (ANOVA test) $p<0.05$ \\
\hline General hotel product & \\
\hline Hotel design and presentation & 0.031 \\
Location accessibility and visibility & 0.029 \\
\hline Front office & \\
\hline Speedy check-in and check-out & 0.040 \\
Staff courtesy and professionalism & 0.050 \\
Reasonable room rates/value for money & 0.003 \\
\hline Restaurant and bar & \\
\hline Quality color and presentation of food & 0.029 \\
Reasonable restaurant and bar prices & 0.013 \\
Variety of dishes on menu & 0.009 \\
Creativity in service techniques and styles & 0.023 \\
Billing and cashiering procedures & 0.025 \\
Health and dietary & 0.013 \\
\hline Guestroom & \\
\hline Room ambience, quietness, and color & 0.023 \\
Comfort of bedding and seating & 0.040 \\
Quality of fixtures & 0.036 \\
Sufficient fixtures & 0.031 \\
Room maintenance & 0.012 \\
Staff appearance grooming and presentation & 0.041 \\
Staff courtesy and professionalism & 0.017 \\
Voice and accent of staff & 0.018 \\
Language proficiency of employment & 0.030 \\
\hline
\end{tabular}

\section{Role Played by Management Practices in Delivery of Quality Service}

This study identified management practices which had a significant influence on employees' quality service delivery. Mean scores for employees' satisfaction with management practices and the extent to which managers think employees were satisfied were analyzed by an independent $t$-test. The results showed that eight management practices out of 11 were found to be significant. Leadership styles, motivation, training and development, communication at all levels, rewarding styles, employment process, compensation, and employees' welfare were significant at $p \leq 0.05$, as it is showed in Table 2 . 
Table 2

Independent T-test on Satisfaction With Management Practices

\begin{tabular}{llll}
\hline Management practice & Independent $t$-test & $\mathrm{df}$ & Sig. (2-tailed) \\
\hline Leadership styles & 2.022 & 126 & 0.045 \\
Employment process & 2.708 & 122 & 0.008 \\
Motivation & 2.437 & 127 & 0.016 \\
Training and development & 2.459 & 124 & 0.015 \\
Communication at all levels & 2.425 & 124 & 0.017 \\
Empowerment to employees & 0.897 & 126 & 0.371 \\
Performance appraisal & 1.637 & 120 & 0.104 \\
Compensation & 4.065 & 126 & 0.000 \\
Rewarding styles & 2.241 & 122 & 0.027 \\
Commitment to service quality & 1.418 & 123 & 0.159 \\
Employees' welfare & 2.750 & 124 & 0.007 \\
\hline
\end{tabular}

\section{Discussion}

The general hotel products that were assessed include: location accessibility and visibility of the hotel and hotel design and presentation. All these showed a big gap. The gap could be due to poor market information leading to the managers failing to understand guests' requirements (Tsang \& Qu, 2000). Comments from the questionnaires provided evidence for the presence of the gap between customers' expectations and the services offered. Guests commented that the hotels were located far from the airport.

Front office findings showed that staff courtesy and professionalism, speedy check-in and check-out, and reasonable room rates showed a significant gap between what is offered and what is expected. Lack of staff courtesy and professionalism tells managers that there is an urgent need to train their employees in interpersonal skills to catch up with guests' expectations. On the other hand, the gap on check-out and check-in at the reception came from the fact that most of the hotels were operating manually. Bad experience for guests during the check-in and check-out may result in guest dissatisfaction, which in turn leads to guests' ruling out that the service obtained was not equitable to the service delivered (URT, 2002).

The results from the restaurant and bar showed that a variety of dishes on menu, reasonable prices, quality color and presentation of food, creativity in service techniques and styles, billing and cashiering procedures, and health and dietary were significant. This is a clear sign that guests were not satisfied with managers' decisions. Menu stands as a foundation of all activities in the restaurant and bar, hence a discrepancy in menu leads to a discrepancy in other attributes. The scenario could have risen, because the information regarding guests' needs and wants was not interpreted in designing the menus as one of the guests commented on the questionnaire that, "... Menu was not vegan friendly, as it lacks veggies varieties...".

On the other hand, this could be a result of the market department of the hotel failing to collect right information regarding the guests' needs and wants as indicated in the SERVQUAL model (Gržinic, 2007; Tsang \& Qui, 2000).

The understanding of managers in designing quality service in the guestroom did not meet the guests' expectations. The managers' and guests' perceptions differed significantly in several attributes including: quality of fixtures; sufficient fixtures; room maintenance; room ambience, quietness, and color; comfort of bedding and seating; staff appearance grooming and presentation; staff courtesy and professionalism; voice and accent of staff; and language proficiency of hotel employees. 
The situation is confirmed by the comments from the guests:

“... Door lock was not functioning...";

“... Air conditioner malfunctioned, the room was very humid at night...".

This was condition in the hotel, because the management was not committed to quality service in the room. Also, maintenance employees could not translate the specification of room maintenance perfectly. The scenario represents gaps two and three in the SERVQUAL model as the management could have been reluctant to meet the needs of the service quality (Kandampully, 2006).

Delivery of quality service standards depends largely on employees' satisfaction with management practices, since managers' decisions create an internal environment for service delivery (Borucki \& Burke, 1999). In this study, leadership styles, employment process, motivation, training and development, communication, compensation, rewarding styles, and employees' welfare were practices which influenced the delivery of quality service.

The result confirms that, in the researched hotels, employees were not satisfied with the performance of the hotels' management. This could be the reason for poor quality service delivery in most of the areas which were assessed. Bowen and Johnston (1999) commented that the sense of ownership and employees' loyalty are enhanced by treating employees well.

\section{Conclusion and Recommendation}

This study investigated quality service of four areas of a hotel which include general hotel product, front office operation, restaurant and bar, and guestroom. Each investigated area had attributes which respondents had to evaluate in order to determine the level of satisfaction using a 5-point Likert scale. The employees and managements evaluated how their daily responsibilities affect the quality service provision to hotel guests. The results obtained from study inform hotel managers of how to design quality service. It is clear that managers concentrate much on designing buildings with good presentation, facilities, and best front office employees. However, this study provides evidence that restaurant and guestroom services were the most neglected areas. The scenario could have a long rooted problem that stems from training institutions which might be admitting students with lower passes than that of front office students. In general, front office has been receiving special priority that needs excellent employees, because they are at the front of the house where guests receive the first impression. But, the managers must also appreciate that guests spend most of their stay in guestrooms, restaurant and bar, and encounter many moments of truth in these areas which bring the necessity for employees of the said areas to be highly qualified.

The researchers centered their arguments on how hotel managers could create an internal environment for the organization to promote the delivery of quality service. The findings indicated that there was no correction of mistakes and ambiguities which were happening during the delivery of quality service. This means that employees were repeating the same mistakes, hence, managers fail to lock in guests' requirements into quality service specifications.

The researchers recommend that professional boards be established, mandated by the Act of the Parliament of Tanzania within the hospitality profession which will provide guidance on the skill requirements and evaluate the professionals employed within the hotel industry. In addition, the hotel managers should ensure an effective implementation of management practices. 
This study was conducted in Arusha and the guests' respondents were sampled by convenience methods, a non-probability sampling, hence the results of this study cannot be generalized. Therefore, it is recommended that another research be undertaken in other areas such as Zanzibar and Dar-es-Salaam. A different research done in a different place may provide evidence on which area of tourists' destination requires more effort to alleviate the quality service standards.

\section{References}

Anderson, B. A., Provis, C., \& Chappel, S. J. (2003). The selection and training of workers in the tourism and hospitality industries for the performance of emotional labour. Journal of Hospitality and Tourism Management, 10(1), 1-12.

Babakus, E., Yavas, U., Karatepe, M. O., \& Avci, T. (2003). The effect of management commitment to service quality on employees' affective and performance outcomes. Journal of the Academy of Marketing Science, 31(3), 272-286.

Bagherian, M. (2007). Designing service quality in four star hotels based on bound travelers point of view: Case of Safir hotel (Unpublished Master of Marketing and e-Commerce thesis, Lulea University of Technology and University of Esfahan).

Borucki, C. C., \& Burke, M. J. (1999). An examination of service-related antecedents to retail store performance. Journal of Organizational Behavior, 20(6), 943-962.

Bowen, D. E., \& Johnston, R. (1999). Internal service recovery: Developing a new construct. International Journal of Service Industry Management, 10(2), 118-131.

Bowen, D. E., Gilliland, S. W., \& Folger, R. (1999). HRM and services fairness: How being fair with employees spills over to customers. Organizational Dynamics, 27(3), 7-23.

Clark, R. A., Hartline, M. D., \& Jones, K. C. (2009). The effects of leadership style on hotel employees' commitment to service quality. Cornell Hospitality Quarterly, 50(2), 209-231.

Cochran, W. G. (1963). Sampling techniques (2nd ed., p. 462). New York, N.Y.: John Wiley \& Sons, Inc..

Gržinic, D. (2007). Concepts of service quality measurement in hotel industry. Retrieved from http://hrcak.srce.hr/file/24337

Hartog, D., \& Verburg, R. M. (2002). Service excellence from the employees' point of view: The role of first line supervisors. Managing Service Quality: An International Journal, 12(3), 159-164.

Hickman, J., \& Mayer, K. (2003). Service quality and human resource practices: A theme park case study. International Journal of Contemporary Hospitality Management, 15(2), 116-119.

Israel, G. D. (2009). Determining sample size. University of Florida, IFAS Extension. Retrieved from http://edis.ifas.ufl.edu/pdffiles/pd/pd00600.pdf

Kandampully, J. (2006). The new customer-centered business model for the hospitality industry. International Journal of Contemporary Hospitality Management, 18(3), 173-187.

Nadiri, H., \& Hussein, K. (2005). Perceptions of service quality in North Cyprus hotels. International Journal of Contemporary Hospitality Management, 17(6), 469-480.

O’Neill, M. (2001). Measuring the service quality and customer satisfaction. In J. Kandampully, C. Mork, \& B. Spark (Eds.), Service quality management in hospitality, tourism, and leisure (pp. 159-191). New York, N.Y.: The Haworth Hospitality Press.

Pfeffer, J. (1998). The human equation: Building profit by putting people first (pp. 80-85). Boston, M.A.: Harvard Business School Press.

Sigala, M. (2008). Service quality and customer relationship management: Interrelationships and implications. Managing Service Quality: An International Journal, 18(5), 496-511.

Slåtten, T. (2009). The effect of managerial practice on employee-perceived service quality: The role of emotional satisfaction. Managing Service Quality: An International Journal, 19(4), 431-455.

Tanzania Tourist Board [TTB]. (2008). Tourism in Tanzania. Retrieved from http://www.tanzaniatouristboard.com/

Tsang, N., \& Qui, H. (2000). Service quality in China's hotel industry: A perspective from tourists and hotel managers. International Journal of Contemporary Hospitality Management, 12(5), 316-326.

United Republic of Tanzania [URT]. (1999). Tourism policy. Dar-es-Salaam: Government Printers.

United Republic of Tanzania [URT]. (2002). Integrated tourism master plan. Dar-es-Salaam: Ministry Resources Tourism, Tourism Department.

Wadawi, J. K. (2008). An assessment of hotel products quality in Kenya a basis for building destination competitiveness (Unpublished thesis of Doctor of Philosophy Degree, University of Johannesburg, South Africa). 